\title{
A new trophic link between the pelagic and benthic systems on the Antarctic shelf
}

\author{
J.-M. Gilii ${ }^{1 *}$, S. Rossi ${ }^{1}$, F. Pagès ${ }^{1}$, C. Orejas ${ }^{1}$, N. Teixidó ${ }^{1}$, P. J. López-González ${ }^{2}$, \\ W. E. Arntz ${ }^{3}$ \\ ${ }^{1}$ Institut de Ciències del Mar (CSIC), Passeig Marítim de la Barceloneta 37-49, 08003 Barcelona, Spain \\ ${ }^{2}$ Biodiversidad y Ecología de Invertebrados Marinos, Departamento de Fisiología y Zoología, Facultad de Biología, \\ Universidad de Sevilla, Reina Mercedes 6, 41012 Sevilla, Spain \\ ${ }^{3}$ Alfred-Wegener-Institut für Polar und Meeresforschung, Columbusstrasse, 27568 Bremerhaven, Germany
}

\begin{abstract}
During the expeditions EASIZ II and EASIZ III carried out off the Antarctic Peninsula with RV 'Polarstern', a prey, until now never registered, was observed in the gastrovascular cavities of octocorallian Anthomastus bathyproctus colonies. A. bathyproctus gastrovascular contents contained salps of the species Salpa thompsoni in 83 to $88 \%$ of the colonies. Salps represented almost $100 \%$ of the prey items found in the octocorallian polyps. Salp chains were observed drifting just above the sediment. These chains undertook vertical migrations down to a depth of $700 \mathrm{~m}$, reaching the seafloor. The captured salps had stomachs full of microplanktic prey, mainly diatoms and other phytoplankton cells. Fatty acids, considered to be of diatom origin, were detected in the stomachs of salps and in their tunica. The presence of such signature lipids was also detected in the octocorallian coenenchyme, although their concentration was considerably lower. These results suggest that salps may play an important role as a direct grazer of the phytoplankton produced in the top layers of the water column which, in turn, would be directly transferred to A. bathyproctus. An important part of the fresh contents of the salps will be assimilated by the octocorallians. Primary production is captured by a benthic suspension feeder through the grazer, bypassing the faecal pellet rain. The combined filtering activity and vertical migration of salps produces an 'elevator effect', which reduces the loss of energy through this short food chain, thus making the exchange between top and bottom layers more efficient.
\end{abstract}

KEY WORDS: Bentho-pelagic coupling $\cdot$ Antarctic $\cdot$ Salps $\cdot$ Octocorals $\cdot$ Benthic suspension feeders Trophic links Resale or republication not permitted without written consent of the publisher

\section{INTRODUCTION}

The trophic relationships between benthic and water column shelf communities depend mainly on the fuelling from the top water layers to the bottom. Most sessile animals living on the seafloor are strongly dependent on the seasonal input of food from surface water layers in spring-summer to cover their energy demands. This dependence is particularly important in Antarctic environments, due to the strong seasonal pattern of the food particle rain (Honso 2004). Despite this seasonally limited food input, it has been noted that the activity of different groups of suspension feeders does not stop during winter (Barnes \& Clarke 1995). Furthermore, some of these species (all of them suspension feeders) successfully feed on small-plankton communities and detritus (e.g. Oswaldella antarctica, Primnoisis antarctica and Primnoella sp.; Orejas et al. 2003), which are present all year round (Kang et al. 1997).

The strategies of benthic suspension feeders in Antarctica to face feeding constraints are poorly understood. Only a few publications (e.g. Orejas et al. 2003) pay attention to crucial aspects of the diet and 
capture rates, which are essential for understanding the complex structure of Antarctic food chains. In ecosystems such as the Antarctic shelves, most of the sedimenting material is represented by microalgae and faecal pellets (Bathmann et al. 1991). The microalgae that are not consumed by the zooplankton arrive at the bottom without being decomposed and represent a high potential food value for benthic communities (Isla et al. 2006). Also of great importance is the rain of faecal pellets produced by krill and salps, which are extremely abundant organisms in the Antarctic ecosystem (Schnack-Schiel \& Isla 2005). Both taxa generate a high quantity of faecal pellets that, in many cases, contain food items not completely digested when reaching the seafloor (Madin \& Deibel 1998). Although a passive rain of particles in the water column could sustain benthic communities (e.g. Leys et al. 2004), it is likely that complementary trophic chains exist in Antarctic waters, which allow a more efficient exchange between the planktonic and benthic systems. The relevance of the connections between both systems has scarcely been considered, even in very recent reviews of trophic links in the Antarctic.

Zooplankton prey have been observed in some species of Antarctic benthic suspension feeders. In particular, the diet of the hydrozoan Tubularia ralphii consists mainly of copepods, with $85 \%$ of the diet belonging to this group (Orejas et al. 2003). Some species of these copepods migrate through the water column almost down to the bottom (Schnack-Schiel \& Isla 2005). Up to now, this has been the only evidence of the capture of zooplankton by a sessile benthic invertebrate in the Antarctic (Orejas et al. 2003). In some cases, like the alcyonarian Germesia antarctica, unusual capture strategies have been observed (Slattery et al. 1997).

The capture of the pelagic tunicate Salpa thompsoni by the alcyonarian Anthomastus bathyproctus was observed during 2 oceanographic cruises carried out off the Antarctic Peninsula in 1998 and 2000 with RV 'Polarstern'. Both cruises were undertaken within the framework of SCAR's Ecology of the Antarctic Sea Ice Zone (EASIZ) programme. In the present paper the main objective is to demonstrate a trophic relationship between benthic organisms and zooplankton, which represents an alternative in the trophic web to the passive arrival of food from the water column at the bottom.

\section{MATERIALS AND METHODS}

Anthomastus bathyproctus. Distribution and abundance: Photographic transects (i.e. stations) of the seafloor were conducted in the King George Island area (Fig. 1). Sampling was carried out during the ANT XV/3 (EASIZ II) cruise on board RV 'Polarstern' in the austral summer of 1998. A $70 \mathrm{~mm}$ underwater camera (Photosea 70) was used at 7 stations in the 130 to $790 \mathrm{~m}$ depth range (Table 1). At each station, sequences of 40 vertical colour slides (Kodak Ektachrome 64), each covering approximately $1 \mathrm{~m}^{2}$ of the seabed, were randomly taken at evenly spaced time intervals along a transect. The distance between consecutive photographs was about $10 \mathrm{~m}$. A total area of $364 \mathrm{~m}^{2}$ of the sea floor was covered. The optical resolution was approximately $0.3 \mathrm{~mm}$. A total of 280 seafloor photographs were analysed.

Gastrovascular contents: Sampling was conducted with an Agassiz trawl (AGT) during EASIZ II and a bottom trawl (BT) during EASIZ III (Table 1). In total, 38 and 650 colonies were collected during the first and second cruise, respectively. A total of 360 polyps from the 38 colonies of the first cruise were dissected to analyse their gastrovascular cavities. Polyp dissection was done using a binocular and a light microscope. On the second cruise, 60 colonies were examined, measuring the colony diameter, colony height and the polyp basal diameter with a ruler (0.5 $\mathrm{mm}$ precision), and the number of polyps per colony was counted. In these 60 colonies the gastrovascular contents were analysed in the same way as mentioned above, dissecting 660 polyps.

Total lipid and fatty acid analyses: Colonies of Anthomastus bathyproctus were dissected, and the coenenchyme and the emptied polyps were sorted. To calculate the quantity of organic matter in the coenenchyme of $A$. bathyproctus, both parts were

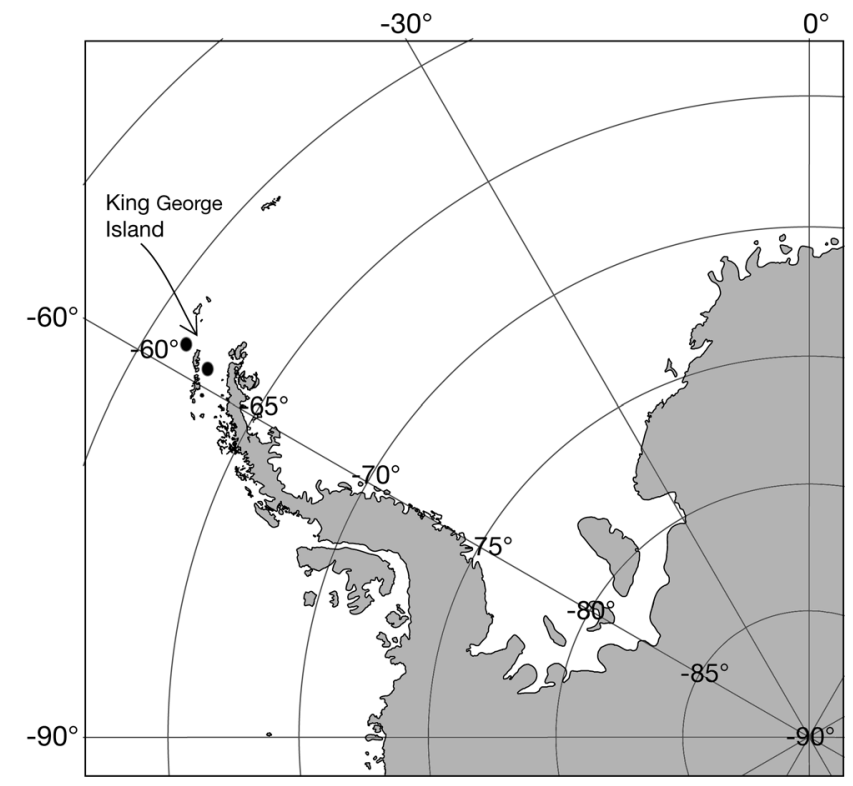

Fig. 1. Research area off King George Island, Antarctic Peninsula. Dots indicate the locations of sampled stations 
Table 1. Sampling stations in the King George Island area. EASIZ: SCAR'S Ecology of the Antarctic Sea Ice Zone programme; PS: photoschaukel; AGT: Agassiz trawl; BT: bottom trawl; MN: multinet

\begin{tabular}{|ccccccccccc}
\hline \multirow{2}{*}{ Year } & Expedition & Stn & \multicolumn{2}{c}{ Position (start) } & \multicolumn{2}{c}{$\begin{array}{c}\text { Position (end) } \\
\text { Lat. (S) }\end{array}$} & Long. (W) & $\begin{array}{c}\text { Depth } \\
\text { (m) }\end{array}$ & $\begin{array}{c}\text { Gear } \\
\text { Lat. (S) }\end{array}$ \\
& & Long. (W) & No. of \\
photos
\end{tabular}

dried $\left(\mathrm{N}=15\right.$ for each part) in the oven at $40^{\circ} \mathrm{C}$ for $48 \mathrm{~h}$; each piece was then weighed and burned in an oven, again at $500^{\circ} \mathrm{C}$ for $4 \mathrm{~h}$. The difference between the dry mass and the ash-free dry mass was considered to be the organic matter of the cnidarians. For A. bathyproctus, 15 to $25 \mathrm{mg}$ dry mass of the coenenchyme $(\mathrm{N}=20)$ and 15 to $20 \mathrm{mg}$ dry mass of the polyps were analysed $(\mathrm{N}=20)$.

The dried tissues of the species were homogenised in 6 to $10 \mathrm{ml}$ of chloroform-methanol (2:1, v/v), depending on the original dry mass of the sample considered. Total lipids were quantified using cholesterol as a standard. To trace the trophic relationship between the 3 food groups in the chain (phytoplankton-salps-anthozoans), a fractionated lipid analysis was performed. Anthomastus bathyproctus colonies were dissected again taking only the coenenchyme $(\mathrm{N}=5)$. The samples were gently ground in a $5 \mathrm{ml}$ glass homogeniser and sonicated $(3 \times 10 \mathrm{~min})$ with $10 \mathrm{ml}$ of $2: 1$ dichloromethane-methanol. The acidic fraction was analysed with gas chromatography following the protocol explained in Rossi et al. (2006).

Salpa thompsoni. Distribution and abundance: Zooplankton sampling was carried out mainly at night at 5 stations located near the 'Anthomastus beds' during the ANT XVII/3 cruise. A multinet $\left(0.25 \mathrm{~m}^{2}\right.$ opening), equipped with 5 nets (mesh size: $100 \mu \mathrm{m}$ ), was used to sample discrete depth ranges in the top $1000 \mathrm{~m}$, or from the bottom to the sea surface at shelf stations (Table 1). The depth ranges were chosen according to the temperature and salinity profiles at each station. All salps were measured using a binocular equipped with a ruler $( \pm 0.5 \mathrm{~mm}$ precision). Five specimens were dissected, and the gut contents were prepared for examination under a scanning electron microscope.
Observations above the bottom: Video images were recorded in autumn 2000 during the ANT XVII/3 cruise. In the Bransfield Strait, the video transects (i.e. stations, Table 1) were performed using the remotely operated vehicle 'Sprint 103' at different depths (30 to $170 \mathrm{~m})$. A total of 3 video transects were analysed, whose lengths varied between 800 and $1000 \mathrm{~m}$. Transect length was determined by the drift of the ship, whereas the width of each transect was determined by 2 parallel laser beams (ca. $0.5 \mathrm{~m}$ ), which served as a scale on the image.

Total lipid and fatty acid analyses: Specimens of Salpa thompsoni were dissected into 2 main parts, the tunica and the stomach. To calculate the organic matter, both parts were dried ( $\mathrm{N}=15$ for each part) in an oven at $40^{\circ} \mathrm{C}$ for $48 \mathrm{~h}$; each piece was then weighed and put in the oven again at $500^{\circ} \mathrm{C}$ for $4 \mathrm{~h}$. The 2 dissected sections were analysed spectrophotometrically. For total lipids, 15 to $40 \mathrm{mg}$ dry weight of the tunica was investigated $(\mathrm{N}=12)$. The stomachs of $S$. thompsoni were also analysed (5 to $20 \mathrm{mg}$ dry weight depending on the stomach volume, $\mathrm{N}=10$ ) using the same technique (Barnes \& Blackstock 1973). Stomachs and tunica of $S$. thompsoni were also searched for signature lipids ( $\mathrm{N}=5$ for each part), using the same protocols described for Anthomastus bathyproctus.

\section{RESULTS}

\section{Distribution and abundance of Anthomastus bathyproctus and Salpa thompsoni}

Colonies of Anthomastus bathyproctus were only present in the photographic transect of Stn 342. Three 
colonies were observed on 2 of the 40 photos taken along this transect (Fig. 2). Even if these results suggested a very low abundance of the species, it was clear from the non-quantitative catches of the bottom and Agassiz trawls that the abundance of this species was very high in some areas (e.g. $>400$ colonies in a 5 min Agassiz trawl), but the distribution of the organisms was extremely patchy.

Chains of Salpa thompsoni were common just above the bottom (Fig. 3). Aggregated blastozooids and solitary oozoids were present throughout the water column by night (we do not have results on distribution

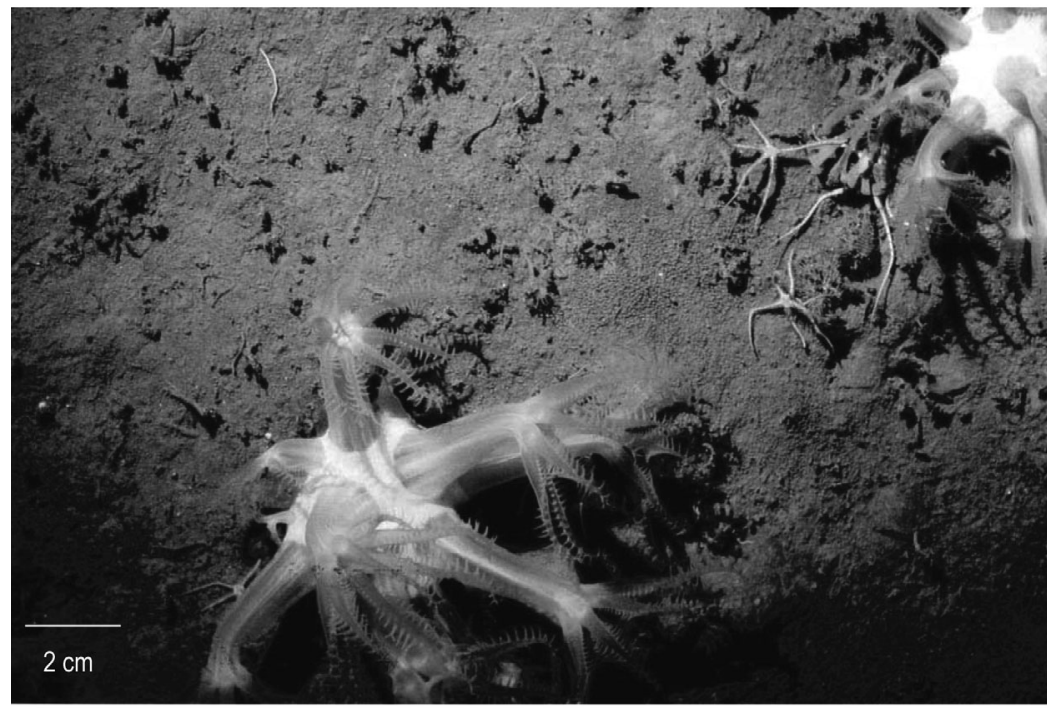

Fig. 2. Anthomastus bathyproctus. Colonies in the King George Island area observed during the ANT XV/3 (1998) cruise at a depth of about $300 \mathrm{~m}$

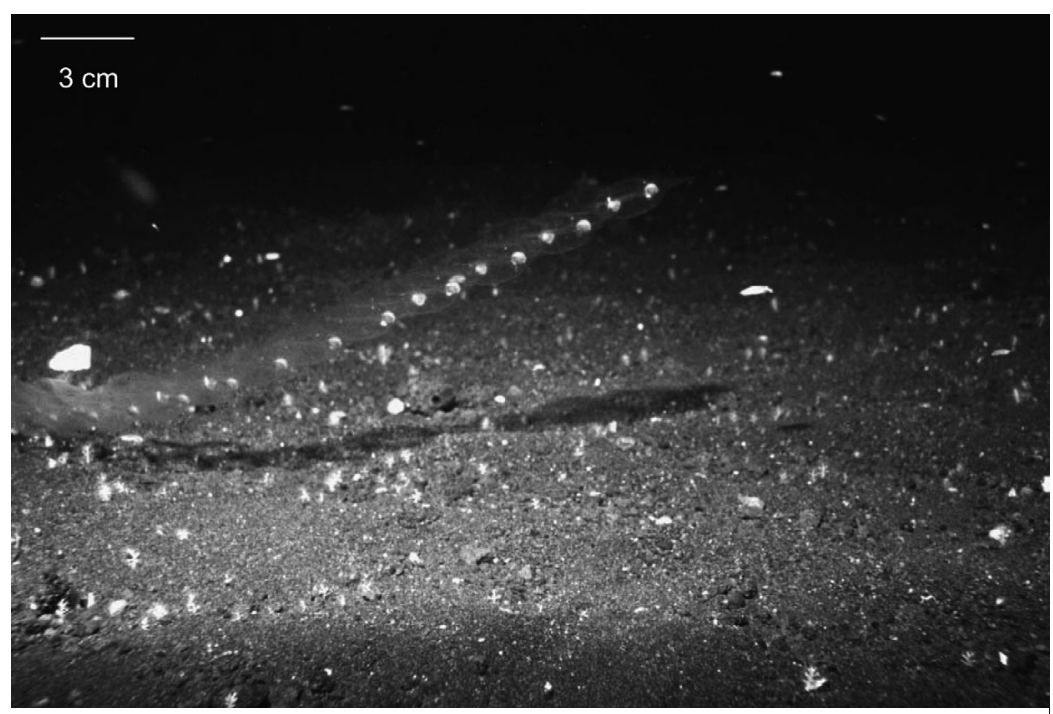

Fig. 3. Salpa thompsoni. A colony (aggregated state) swimming close to the sea floor, recorded with video images in autumn 2000 in the King George Island area at a depth of about $800 \mathrm{~m}$. Dots in the photographs are the gastrointestinal tracts of individual zooids (scale bar refers only to the size of salps) during daytime). The highest density of salps was found at Stn 187-2 (Table 1, Fig. 4), with 4.8 ind. $\mathrm{m}^{-3}$ at a depth of $300 \mathrm{~m}$, close to the bottom.

\section{Trophic ecology of Anthomastus bathyproctus}

The average $( \pm \mathrm{SD})$ diameter of Anthomastus bathyproctus colonies was $44.2 \pm 6.7 \mathrm{~mm}$ and the average $( \pm \mathrm{SD})$ height was $54.3 \pm 7.6 \mathrm{~mm}$. Each colony had 7 to 18 polyps, and the basal part (average \pm SD diameter) of each polyp was $6.7 \pm 3.4 \mathrm{~mm}$. No differences were observed among the number of polyps per colony related to different colony sizes or depths. The mean $( \pm \mathrm{SD})$ number of prey per polyp was $0.8 \pm 0.6$ in the summer cruise ANT XV/3 (1998) and $0.2 \pm 0.2$ in the autumn cruise ANT XVII/3 (2000). Similar numbers of full colonies (colonies containing at least 1 polyp with gut contents) were found in both cruises: 83 and $88 \%$, respectively. There were no differences in the number of prey per polyp between both cruises. The maximum number of prey per polyp was 6 . The size of the main prey item (salps) was between 10 and $50 \mathrm{~mm}$ during both cruises. The polyps also contained other food items (mainly diatoms of the genus Corethron, centric diatoms and small sized faecal pellets). However, these food items seemed to be from the stomachs of the salps. Examination of the phytoplankton cells under a scanning microscope showed that they were not digested (Fig. 5).

Total lipids were up to 5 times more concentrated in the Salpa thompsoni stomachs than in the tunica. In contrast, Anthomastus bathyproctus total polyp lipids had a similar concentration to that in $S$. thompsoni stomachs, whereas the total lipids in the anthozoan coenenchyme were almost twice the values found in the polyps (Table 2).

To enhance the role of the primary producer (diatoms) trace through the trophic chain, we chose a combined set of 3 signature lipids (fatty acids) considered representative of this group, specifically 14:0, 16:1(n-7) and 20:5(n$6)$. The proportion of the 3 markers decreased from Salpa thompsoni stomach contents (that could be considered 


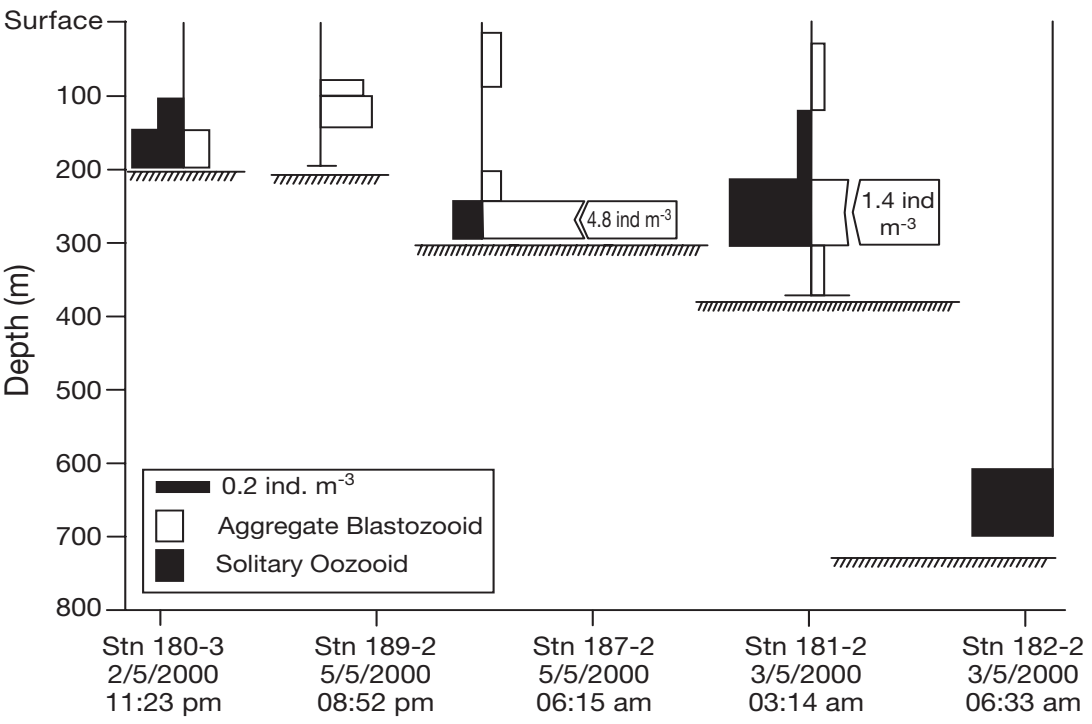

Fig. 4. Salpa thompsoni. Scheme of the vertical distribution in the King George Island area during the ANT XVII/3 cruise in May 2000
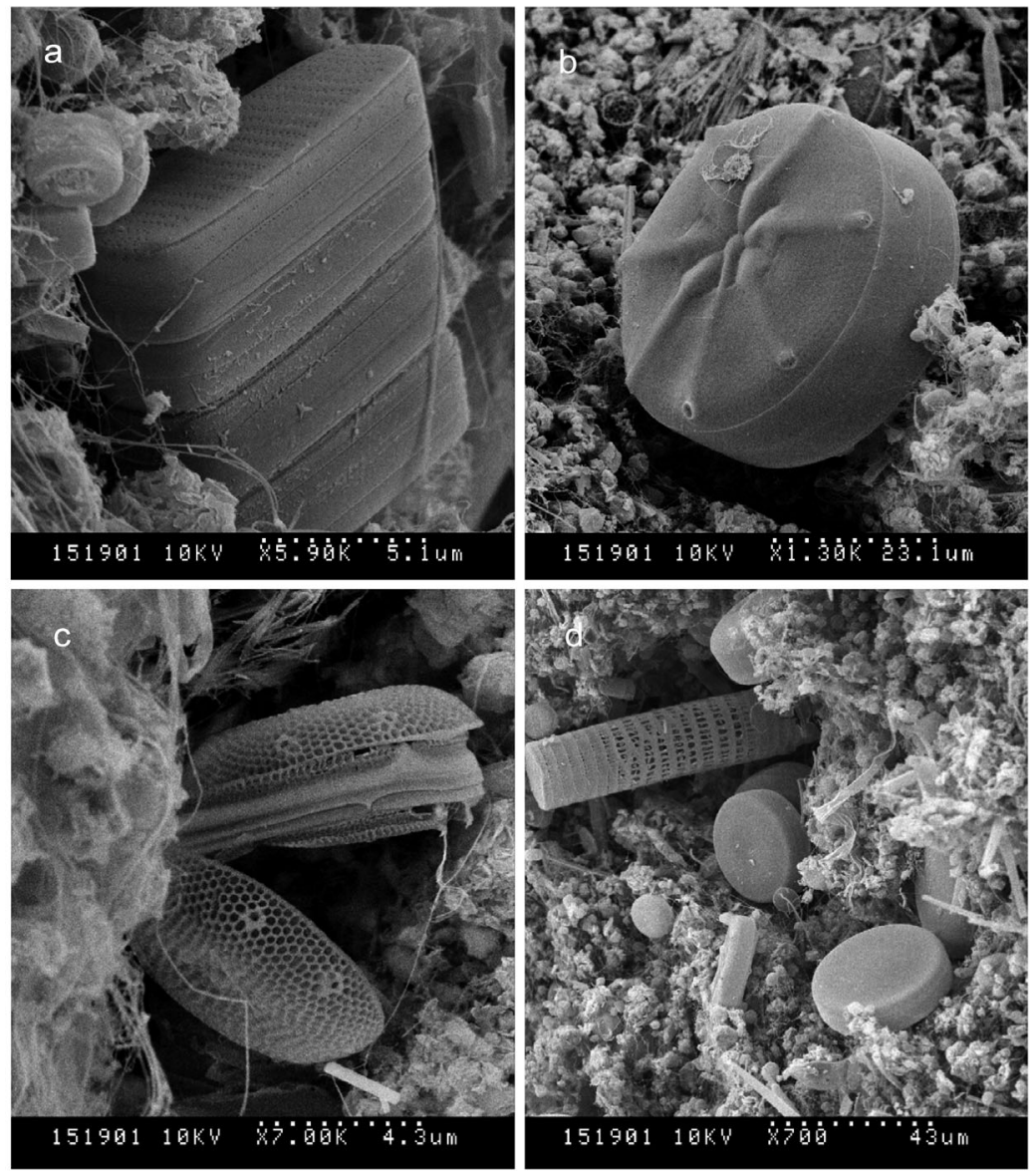

Fig. 5. Salpa thompsoni. Electron microscope images of the stomach contents of 1 specimen captured by a polyp of Anthomastus bathyproctus (image prepared by José-Manuel Fortuño, Electronic Microscope Service of ICMCSIC): (a) Fragillariopsis sp., (b) Asteromphalus sp., (c) Thalassiosira sp. and (d) Dactyliosolen sp. almost $100 \%$ filtered seston material) to Anthomastus bathyproctus tissues, which indicates that diatoms were a part of the food intake (Table 2). In the $A$. bathyproctus coenenchyme the signal was weaker compared to that in the salp tunica.

\section{DISCUSSION}

The photographic sampling performed for Anthomastus bathyproctus was not sufficient to supply quantitative data on its density, but allows us to interpret a similar patchy distribution to that found previously in another sessile Antarctic anthozoan, Ainigmaptilon antarcticum (Orejas et al. 2002). Related to the salps, we observed that the anthozoans occurred throughout the whole water column at night, mostly in deep layers near the bottom, and more frequently than was presumed from the available literature (e.g. Lancraft et al. 1989). Salpa thompsoni has been reported to carry out diel migrations, reaching depths of $400 \mathrm{~m}$ or more (Nishikawa \& Tsuda 2001). However, we have no direct evidence that diel migration was involved in this particular case.

The high number of salps captured by the alcyonarians is related to the high abundances (e.g. up to 4.8 ind. $\mathrm{m}^{-3}$; Fig. 4) of Salpa thompsoni occurring near the sea floor. Our results, with vertical distribution ranging from 300 to $400 \mathrm{~m}$, agree with those found in the literature; $S$. thompsoni is specifically cited to be among the Antarctic species with wider vertical distributions related to diel migratory behaviour (Nishikawa \& Tsuda 2001). To our knowledge this is the first study that has video recorded chains of salps swimming close to the bottom (Fig. 3), deeper than 200 m. Mass occurrence of salp chains may contribute to sustain the populations of $A$. bathyproctus. The faecal pellets produced by the salps should also contribute to fuel other benthic organisms that may feed on minor size fractions of the seston (e.g. Oswaldella antarctica, Primnoisis antarctica and Primnoella sp.; Orejas et 
Table 2. Salpa thompsoni, Anthomastus bathyproctus. Total lipids and fatty acids (fractionate lipids, considered to be mainly of diatom origin) from the different steps in the trophic chain. Total lipids are given as absolute values ( $\left.\mu \mathrm{g} \mathrm{mg}^{-1}\right)$; fatty acids, as a percentage of the total fatty acids (polar fraction). Data are mean values (standard deviation in parentheses)

\begin{tabular}{|lcccc|}
\hline & Total lipids & $14: 0$ & $16: 1(\mathrm{n}-7)$ & $20: 5(\mathrm{n}-3)$ \\
\hline Salp stomach & $147(27)$ & $8.8(1.4)$ & $8.6(0.8)$ & $6.8(2.5)$ \\
Salp tunica & $27(9)$ & $6.1(1.2)$ & $6.7(0.8)$ & $6.8(4.4)$ \\
Anthomastus polyp & $176(68)$ & - & - & - \\
Anthomastus coenenchyme & $326(130)$ & $1.2(0.3)$ & $3.6(0.6)$ & $0.3(0.2)$ \\
\hline
\end{tabular}

al. 2003). However, faecal pellets and benthic diatoms have never been observed in alcyonarian stomachs. This food source has already been proposed to explain the presence of dense communities of sponges at $500 \mathrm{~m}$ depth or other communities in the deep sea dominated by suspension feeders (Leys et al. 2004).

During migration, salps do not stop filtering (Madin \& Deibel 1998). It is likely that they also feed on the seston or marine snow near the bottom, as has been shown for several zooplankton groups like harpacticoid copepods (Koski et al. 2005). Salps digest the food filtered in the surface layers throughout the descent. Therefore, the salps and their stomach contents represent food with a high nutritional value (Fortier et al. 1994). When salps are dominant, they can consume $>75 \%$ of the daily primary production in the surface layers of Antarctic waters (Huntley et al. 1989). If the content of the stomachs is only partially digested by the salps (Madin \& Deibel 1998), it is likely that a considerable proportion of the primary production could represent a significant food source for benthic communities. Dense swarms of salps may thus cover a high percentage of the daily demand of some benthic fauna (Wiebe et al. 1979). Salps represent a kind of prey with a high energetic content (Fortier et al. 1994), and should be an efficient link between the lowest trophic level of the photic layer (i.e. the phytoplankton) and the macrobenthos. During the austral spring and summer, when the populations of salps are abundant and migrate close to the bottom, the alcyonarian colonies can accumulate a large quantity of reserve material that can be subsequently used when they only find smaller seston particles (Orejas et al. 2003).

The similar lipid contents of salp stomachs and the polyp tissue of the alcyonarian suggest a direct transfer of energy between predator and prey. On the other hand, the high concentration of lipids observed in the coenenchyme of Anthomastus bathyproctus could be due to the accumulation of lipids from undigested prey (mainly diatoms) present in the stomachs of the salps caught (Fahl \& Kattner 1993). The fractionated lipids help to interpret the results of this study. The presence of combined markers, considered mostly of bacillariophytic origin (Fahl \& Kattner 1993), decreases as the level in the trophic chain increases. Despite the possible breakdown of certain markers inside the zooplankton (Prahl et al. 1984), the trophic signature indicates that a large part of the phytoplankton is of diatom origin. It can be hypothesised that the alcyonarians partially assimilate phytoplankton cells that have not been previously digested by salps. A similar linkage has been observed between the salps and a commensal hyperiid amphipod species (Phleger et al. 2000), in which the presence of fatty acids and stanols from microalgae in the crustacean tissues allowed a trace of the trophic relationship between the host, the filtered phytoplankton and the commensal.

In a general context, short, well-structured chains are more common in ecosystems with low productivity and in environments that change drastically with time (Cohen 1989). The length of a chain is related to the quantity of energy and the amount that is transformed and transmitted along its length (Margalef 1974). In many ecosystems, such as the Antarctic, trophic chains have usually been defined based only on the relationships within the pelagic and the benthic subsystems, separating both as individual blocks. In the present study, the initial link represents the food that enters the system (pelagic primary producers), which is then transmitted within the same subsystem to the first consumer link and is subsequently exported to another subsystem (the benthos) (Gili et al. 2001). This model could also be valid if we consider only passive arrival of particles and seston at the bottom. The production of faecal pellets would then be the joining link between planktonic and benthic subsystems. Conversely, the role of the salps described in the present study leads to the concept of mixed trophic chains between subsystems.

Acknowledgements. We thank Richard Crawford, Marta Ferrario and Nagore Sampedro for their help with the identification of diatoms, and 3 anonymous reviewers for their comments that very much improved the final version of the manuscript. Financial support for this study was provided by the Spanish Antarctic Research Programme, Grants ANT19991608-E, REN2000-3096-E/ANT and REN2003-04236, and by the programme Acciones Integradas of the Spanish Ministerio de Asuntos Exteriores and Deutscher Akademischer Austauschdienst (DAAD), Grant 314-Al-e-dr. The Spanish authors are also indebted to the Alfred Wegener Institute for Polar and Marine Research (AWI), which kindly invited them to join both EASIZ expeditions. Many colleagues who assisted on board and the readiness of the crew of the RV 'Polarstern' to help are also gratefully acknowledged. 


\section{LITERATURE CITED}

Barnes H, Blackstock J (1973) Estimation of lipids in marine animal tissues: detailed investigation of the sulphophosphovanillin method for 'total' lipids. J Exp Mar Biol Ecol 12:103-118

Barnes DKA, Clarke A (1995) Seasonality of feeding activity in Antarctic suspension feeders. Polar Biol 15:335-340

Bathmann U, Fischer G, Müller PJ, Gerdes D (1991) Shortterm variations in particulate matter sedimentation off Kapp Norvegia, Weddell Sea, Antarctica: relation to water mass advection, ice cover, plankton biomass and feeding activity. Polar Biol 11:185-195

Cohen JE (1989) Food webs and community structure. In: Roughgarden J, May RM, Levin SA (eds) Perspectives in ecological theory. Princeton University Press, Princeton, NJ, p 181-202

Fahl K, Kattner G (1993) Lipid content and fatty acid composition of algal communities in sea-ice and water from the Weddell Sea (Antarctica). Polar Biol 13:405-409

Fortier L, Le Fèvre J, Legendre L (1994) Export of biogenic carbon to fish and to the deep ocean: the role of large planktic microphages. J Plankton Res 16:809-839

Gili JM, Coma R, Orejas C, López-González PJ, Zavala M (2001) Are Antarctic suspension feeding communities different from those elsewhere in the world? Polar Biol 24: $473-485$

Honso S (2004) Particle export and the biological pump in the Southern Ocean. Antarct Sci 16:501-516

Huntley ME, Sykes PF, Marin V (1989) Biometry and trophodynamics of Salpa thompsoni Foxton (Tunicata: Thaliacea) near the Antarctic Peninsula in austral summer, 1983-1984. Polar Biol 10:59-70

Isla E, Gerdes D, Palanques A, Gili JM, Arntz WE (2006) Particle flux near the continental ice edge on the eastern Weddell Sea shelf. Deep-Sea Res II 53:866-874

Kang JS, Kangh SH, Lee JH, Chung KH, Lee MY (1997) Antarctic micro- and nano-sized phytoplankton assemblages in the surface water of Maxwell Bay during the 1997 austral summer. Korean J Polar Res 8:35-45

Koski M, Kiørboe T, Takahashi K (2005) Benthic life in the pelagic: aggregate encounter and degradation rates by pelagic harpacticoid copepods. Limnol Oceanogr 50: 1254-1263

Editorial responsibility: Otto Kinne (Editor-in-Chief), Oldendorf/Luhe, Germany
Lancraft TM, Torres JJ, Hopkins TL (1989) Micronekton and macrozooplankton in the open waters near Antarctic ice edge zones (AMERIEZ-1983 and AMERIEZ-1986). Polar Biol 9:225-233

Leys SP, Wilson K, Holeton C, Reiswig HM, Austin WC, Tunnicliffe V (2004) Patterns of glass sponge (Porifera, Hexactinellida) distribution in coastal waters of British Columbia, Canada. Mar Ecol Prog Ser 283:133-149

Madin LP, Deibel D (1998) Feeding and energetics of Thaliacea. In: Bone Q (ed) The biology of pelagic tunicates. Oxford University Press, Oxford, p 81-103

Margalef R (1974) Ecología. Editorial Omega, Barcelona

Nishikawa J, Tsuda A (2001) Diel vertical migration of the tunicate Salpa thompsoni in the Southern Ocean during summer. Polar Biol 24:299-302

Orejas C, López-González PJ, Gili JM, Teixidó N, Arntz WE (2002) Abundance and reproductive ecology of an Antarctic octocoral Ainigmaptilon antarcticum in the Weddell Sea. Mar Ecol Prog Ser 231:101-114

Orejas C, Gili JM, Arntz W (2003) The role of small-plankton communities in the diet of two Antarctic octocorals (Primnoisis antarctica and Primnoella sp.). Mar Ecol Prog Ser 250:105-116

Phleger CF, Nelson MN, Mooney B, Nichols PD (2000) Lipids of Antarctic salps and their commensal hyperiid amphipods. Polar Biol 23:329-337

Prahl FG, Eglinton G, Corner EDS, O'Hara SCM, Forsberg EV (1984) Changes in plant lipids during passage through the gut of Calanus. J Mar Biol Assoc UK 64:317-334

Rossi S, Sabatés A, Latasa M, Reyes E (2006) Fatty acid composition in different trophic groups as an indicator of food intake in the anchovy (Engraulis encrasicolus) larvae in the NW Mediterranean. J Plankton Res 28:551-562

Schnack-Schiel SB, Isla E (2005) The role of zooplankton in the pelagic-benthic coupling of the Southern Ocean. Sci Mar 69(Suppl 2):39-55

Slattery M, McClintock JB, Bowser SS (1997) Deposit feeding: a novel model of nutrition in the Antarctic colonial soft coral Germesia antarctica. Mar Ecol Prog Ser 149: 299-304

Wiebe PH, Madin LP, Haury LR, Harbison GR, Philbin LM (1979) Diel vertical migration by Salpa aspera and its potential for large-scale particulate organic matter transport to the deep sea. Mar Biol 53:249-255

Submitted: October 31, 2005; Accepted: March 29, 2006

Proofs received from author(s): September 6, 2006 